\title{
Preparation, Crystal Structure and
} Spectroscopy Characterization of Vanadium(V) Complex, 2-Amino-4-Picolinium, 2-Methylimidazolium Decavanadate Hydrate $\left(\mathrm{C}_{4} \mathrm{~N}_{2} \mathrm{H}_{7}\right)_{4}\left(\mathrm{C}_{6} \mathrm{~N}_{2} \mathrm{H}_{10}\right) \mathrm{V}_{10} \mathrm{O}_{28} \cdot 2 \mathrm{H}_{2} \mathrm{O}$

\author{
Myriam Louati1 , Regaya Ksiksi',2, Laurent Jouffret ${ }^{3}$, Mohamed Faouzi Zid1 \\ ${ }^{1}$ University of Tunis El Manar, Faculty of Sciences of Tunis, Laboratory of Materials, Crystal Chemistry and Applied \\ Thermodynamics, Tunis, Tunisia \\ ${ }^{2}$ The Higher Institute of Preparatory Studies in Biology and Geology (ISEP-BG) of Soukra, Carthage University, Tunisia, Tunisia \\ ${ }^{3}$ Clermont Auvergne University, Clermont-Ferrand, France \\ Email: faouzi.zid@fst.rnu.tn
}

How to cite this paper: Louati, M., Ksiksi, R., Jouffret, L. and Zid, M.F. (2019) Preparation, Crystal Structure and Spectroscopy Characterization of Vanadium(V) Complex, 2-Amino-4-Picolinium, 2-Methylimidazolium Decavanadate Hydrate $\left(\mathrm{C}_{4} \mathrm{~N}_{2} \mathrm{H}_{7}\right)_{4}\left(\mathrm{C}_{6} \mathrm{~N}_{2} \mathrm{H}_{10}\right) \mathrm{V}_{10} \mathrm{O}_{28} \cdot 2 \mathrm{H}_{2} \mathrm{O}$. Crystal Structure Theory and Applications, 8, 1-11. https://doi.org/10.4236/csta.2019.81001

Received: January 22, 2019

Accepted: February 23, 2019

Published: February 26, 2019

Copyright $\odot 2019$ by author(s) and Scientific Research Publishing Inc. This work is licensed under the Creative Commons Attribution International License (CC BY 4.0).

http://creativecommons.org/licenses/by/4.0/

\begin{abstract}
A new decavanadate, $\left(\mathrm{C}_{4} \mathrm{~N}_{2} \mathrm{H}_{7}\right)_{4}\left(\mathrm{C}_{6} \mathrm{~N}_{2} \mathrm{H}_{10}\right) \mathrm{V}_{10} \mathrm{O}_{28} \cdot 2 \mathrm{H}_{2} \mathrm{O}$, was synthesized by slow evaporation at room temperature and characterized by single crystal $\mathrm{X}$-ray diffraction, IR and UV-Vis spectroscopies. The compound crystallizes in the triclinic system, $\mathrm{P}-1$ space group with the cell parameters: $\mathrm{a}=11.200(5) \AA, \mathrm{b}=$ 12.056(9) $\AA, \mathrm{c}=20.511(7) \AA, \alpha=73.40(4), \beta=84.67(3), \gamma=63.51(5), \mathrm{Z}=2$ and volume $\mathrm{V}=2373.7(1) \AA^{3}$. The formula unit is composed of one decavanadate $\left[\mathrm{V}_{10} \mathrm{O}_{28}\right]^{6-}$ anion, four 2-methylimidazolium $\left(\mathrm{C}_{4} \mathrm{~N}_{2} \mathrm{H}_{7}\right)^{+}$cations, one 2-amino-4-picolinium $\left(\mathrm{C}_{6} \mathrm{~N}_{2} \mathrm{H}_{10}\right)^{2+}$ cation and two water molecules. In the crystal, the layers of decavanadate groups, organic cations and water molecules stack up parallel to the (011) plane. The cohesion is provided by $\mathrm{N}-\mathrm{H} \cdots \mathrm{O}, \mathrm{O}-\mathrm{H} \cdots \mathrm{O}$ hydrogen bonds and Van der Waals interactions leads to a three-dimensional structure. The absorbance spectrum measurement shows an optical band gap of $3.27 \mathrm{eV}$ which allows us to conclude that this compound is a semiconductor material.
\end{abstract}

\section{Keywords}

Decavanadate, Synthesis, X-Ray Analysis, Crystal Structure, Semiconductor Material 


\section{Introduction}

Polyoxometalates (POMs) are a kind of inorganic clusters, which can be combined with organic ligands and metal ions to form supramolecular compounds. These groups have been extensively studied due to their potential applications in various fields such as catalysis [1] and materials science [2]. The size and the structure are two important criteria among others that determine the properties and hence the applications of these species.

Among the various types of POMs, decavanadate represents an important part of the group which has been studied extensively in the past decades because of their excellent catalysis properties [3] [4] and versatile bioactivities [5] [6] [7] [8]. In addition, the decavanadate anion $\left[\mathrm{V}_{10} \mathrm{O}_{28}\right]^{6-}$ has been characterized by numerous cations for antibacterial, antidiabetes and catalytic activities [9]-[17]. Recently, organic decavanadates have been synthesized with the aim to understand their biological [18], magnetic [19], and optical properties [20].

Several decavanadate compounds containing organic cations have been synthesized such us: $\left(\mathrm{C}_{5} \mathrm{H}_{12} \mathrm{~N}\right)_{9}\left[\mathrm{HV}_{10} \mathrm{O}_{28}\right]\left(\mathrm{NO}_{3}\right)_{4}$ [21], $\left(\mathrm{C}_{7} \mathrm{H}_{10} \mathrm{~N}\right)_{4}\left[\mathrm{H}_{2} \mathrm{~V}_{10} \mathrm{O}_{28}\right] \cdot 2 \mathrm{H}_{2} \mathrm{O}$ [22], $\quad\left(\mathrm{C}_{12} \mathrm{H}_{12} \mathrm{~N}_{2}\right)_{3}\left(\mathrm{~V}_{10} \mathrm{O}_{28}\right) \cdot 2 \mathrm{H}_{2} \mathrm{O} \quad[23], \quad\left[\mathrm{C}_{8} \mathrm{NH}_{20}\right]_{9}\left[\mathrm{H}_{2} \mathrm{~V}_{10} \mathrm{O}_{28}\right]\left[\mathrm{HV}_{10} \mathrm{O}_{28}\right] \cdot 2 \cdot 13 \mathrm{H}_{2} \mathrm{O}$ [24].

In a continuation of these studies, a new decavanadate compound containing organic cations has been prepared.

In this paper, we report the synthesis, crystal structure, IR and UV-Vis spectroscopies of the novel decavanadate $\left(\mathrm{C}_{4} \mathrm{~N}_{2} \mathrm{H}_{7}\right)_{4}\left(\mathrm{C}_{6} \mathrm{~N}_{2} \mathrm{H}_{10}\right) \mathrm{V}_{10} \mathrm{O}_{28} \cdot 2 \mathrm{H}_{2} \mathrm{O}$.

\section{Experimental}

\subsection{Synthesis and Crystallization of 2-Amino-4-Picolinium, 2-Methylimidazolium Decavanadate Hydrate: $\left(\mathrm{C}_{4} \mathrm{~N}_{2} \mathrm{H}_{7}\right)_{4}\left(\mathrm{C}_{6} \mathrm{~N}_{2} \mathrm{H}_{10}\right) \mathrm{V}_{10} \mathrm{O}_{28} \cdot 2 \mathrm{H}_{2} \mathrm{O}$ (1)}

The compound $\left(\mathrm{C}_{4} \mathrm{~N}_{2} \mathrm{H}_{7}\right)_{4}\left(\mathrm{C}_{6} \mathrm{~N}_{2} \mathrm{H}_{10}\right) \mathrm{V}_{10} \mathrm{O}_{28} \cdot 2 \mathrm{H}_{2} \mathrm{O}$ was prepared from a mixture of $0.321 \mathrm{~g}$ of vanadium oxide $\mathrm{V}_{2} \mathrm{O}_{5}, 0.091 \mathrm{~g}$ of 2-methylimidazole $\left(\mathrm{C}_{4} \mathrm{H}_{6} \mathrm{~N}_{2}\right)$ and $0.057 \mathrm{~g}$ of 2-amino-4-picoline $\left(\mathrm{C}_{6} \mathrm{H}_{8} \mathrm{~N}_{2}\right)$ in water. The mixture obtained was stirred and heated for about 3 hours. Finally, the solution was allowed to stand at room temperature and after a week, single orange crystals suitable for ray diffraction analysis were obtained.

\subsection{X-Ray Diffraction Study}

The collect of diffracted intensities was performed using an Enraf-Nonius CAD4 four-circle diffractometer with $\mathrm{K}_{\alpha}$ radiation of molybdenum $(\lambda=0.71067 \AA)$. The structure was solved by direct method using the SHELXS-97 program [25] and refined by the full-matrix least squares method on all $\mathrm{F}^{2}$ data using the program SHELXL-2014 [26].

Anisotropic thermal parameters were used to refine all the non-hydrogen.

$\mathrm{B}$ atoms and the positions of the hydrogen atoms were calculated using the HFIX instruction. 
Crystal data and details on data collection and refinement are summarized in Table 1.

DIAMOND [27] package was used for molecular graphics. CIF file containing complete information about the structure of (1) was deposited with the Cambridge Crystallographic Data Center (CCDC 1908881). The file is freely available upon request from the following web site:

https://www.ccdc.cam.ac.uk/data_request/cif.

\subsection{X-Ray Powder Diffraction Study of Compound (1)}

The purity of phase (I) were checked by comparing, using the Origin software [28], the experimental diffractogram $\left(\lambda_{\mathrm{Cu}}(\mathrm{Ka} 1)=1.5406 \AA\right)$ with the calculated diffractogram from single-crystal X-ray diffraction data, obtained using the VESTA program [29]. The superposition of the two diffractograms (Figure 1) confirms the purity of the sythesized phase.

Table 2 groups the different peaks, their indications and their intensities.

\subsection{IR Spectra of Compound (1)}

In Figure 2, we present the IR spectrum of the compound (1) (Pellets with $\mathrm{KBr}$, mg: analyte 2, $\mathrm{KBr} 250$; Perkin-Elmer spectrometer) $\mathrm{cm}^{-1}: 585,608,745,830$ $v\left(\mathrm{VO}_{6}\right), 970 v(\mathrm{~V}=\mathrm{O}), 1310 v(\mathrm{C}=\mathrm{C})$ and cycle vibrations, $1430 v(\mathrm{C}=\mathrm{N}), 1610$ $\delta(\mathrm{O}-\mathrm{H}), 1830,1930,2690 v(\mathrm{C}-\mathrm{H}), v(\mathrm{C}-\mathrm{N}), v(\mathrm{~N}-\mathrm{H})$ and $v(\mathrm{C}-\mathrm{C}), 2905$ hydrogen bonds, 3095, 3145, $3365 v(\mathrm{O}-\mathrm{H})$.

\subsection{UV-Vis Spectra of Compound (1)}

The UV-Vis spectra were recorded on a T70/T70 + UV-V is spectrophotometer in the range $200-700 \mathrm{~nm}$ (Figure 3). The UV-Vis spectrum of 1 displays two intense absorption bands. The band observed at $300 \mathrm{~nm}$ can be assigned to charge-transfer $(\mathrm{CT})$ transitions of the type $\pi(\mathrm{O}) \rightarrow \mathrm{d}(\mathrm{V})$ and the band at 494.64 $\mathrm{nm}$ can be explained the color (orange) of crystals of the title compound. The band gap is estimated by extrapolation of the linear part. The absorbance spectrum measurement shows an optical band gap of $3.27 \mathrm{eV}$ which allows us to conclude that this compound is a semiconductor material (the gap energy is less than $4 \mathrm{eV}$ ).

\section{Results and Discussion}

The formula unit is composed of one decavanadate $\left[\mathrm{V}_{10} \mathrm{O}_{28}\right]^{6-}$ anion, four 2-methylimidazolium $\left(\mathrm{C}_{4} \mathrm{~N}_{2} \mathrm{H}_{7}\right)^{+}$cations, one 2-amino-4-picolinium $\left(\mathrm{C}_{6} \mathrm{~N}_{2} \mathrm{H}_{10}\right)^{2+}$ cation and two water molecules (Figure 4).

Each decavanadate cluster is composed by ten distorted edge-sharing $\mathrm{VO}_{6}$ octahedra. In fact, the distortion indexes vary between 7.6\% and 9.9\% [30] (Table $3)$. The vanadium is in the +5 oxidation. This result was confirmed by the bond valence sums calculations (Table 3) according to Brown [31] [32] $(\mathrm{S}=\Sigma \mathrm{si}=$ $\sum \exp \left[\left(\mathrm{R}_{0}-\mathrm{R}_{\mathrm{i}}\right) / \mathrm{B}\right]$. The $\mathrm{V}-\mathrm{O}_{\text {terminal }}$ bond distances range between 1.593(4) and 1.621(4) $\AA$. The $\mathrm{V}-\mathrm{O}_{2 \mathrm{~b}}$ bonds are in the range of 1.678(4) and 2.071(4) $\AA$. The 
Table 1. Crystallographic characteristics, the X-ray data collection and structure-refinement parameters for $\left(\mathrm{C}_{4} \mathrm{~N}_{2} \mathrm{H}_{7}\right)_{4}\left(\mathrm{C}_{6} \mathrm{~N}_{2} \mathrm{H}_{10}\right) \mathrm{V}_{10} \mathrm{O}_{28} \cdot 2 \mathrm{H}_{2} \mathrm{O}$.

\begin{tabular}{|c|c|}
\hline System, sp. gr., Z & Triclinic, $P-1,2$ \\
\hline$a, b, c, \AA$ & $11.200(5), 12.056(9), 20.511(7)$ \\
\hline$\alpha, \beta, \gamma \operatorname{deg}$ & $73.40(4), 84.67(3), 63.51(5)$ \\
\hline$V, \AA^{3}$ & $2373.58(1)$ \\
\hline$D_{\mathrm{x}}, \mathrm{g} \cdot \mathrm{cm}^{-3}$ & 2.01 \\
\hline Radiation, $\lambda, \AA$ & $\mathrm{MoK}_{\omega} 0.71073$ \\
\hline$\mu, \mathrm{mm}^{-1}$ & 1.976 \\
\hline$T, \mathrm{~K}$ & $298(2)$ \\
\hline Sample size, $\mathrm{mm}$ & $0.25 \times 0.19 \times 0.15$ \\
\hline Diffractometer & ENRAF-NONIUS CAD4 \\
\hline Scan mode & $\omega / 2 \theta$ \\
\hline Absorption correction & Psi-scan \\
\hline$T_{\min }, T_{\max }$ & $0.8027,0.9979$ \\
\hline$\theta_{\max }, \mathrm{deg}$ & 26.984 \\
\hline$h, k$, lranges & $-14 \leq h \leq 1,-15 \leq k \leq 14,-26 \leq 1 \leq 26$ \\
\hline Number of reflections: measured/unique & $11024 / 10252(N 1)$ \\
\hline$R_{\text {int }}$ & 0.029 \\
\hline Number of reflections with I $>2 \sigma(\mathrm{I})$ & $5525(\mathrm{~N} 2)$ \\
\hline Number of refined parameters & 662 \\
\hline$R 1 / w R 2$ relative to $\mathrm{N} 1$ & $0.084 / 0.181$ \\
\hline$R 1 / w R 2$ relative to $\mathrm{N} 2$ & $0.059 / 0.162$ \\
\hline$S$ & 1.021 \\
\hline$\Delta \rho_{\max } / \Delta \rho_{\min }, \mathrm{e} \cdot \AA^{-3}$ & $1.325 /-0.923$ \\
\hline Programs & SHELXS-97 [25], SHELXL-2014 [26], DIAMOND [27] \\
\hline
\end{tabular}

Table 2. Indexation of DRX diffractogram of compound (1).

\begin{tabular}{cccccccccc}
\hline $\mathbf{h}$ & $\mathbf{k}$ & $\mathbf{1}$ & $\mathbf{2 \theta}\left(^{\circ}\right)$ & $\mathbf{I} / \mathrm{I}_{0}$ & $\mathbf{h}$ & $\mathbf{k}$ & $\mathbf{l}$ & $\mathbf{2 \theta}\left(^{\circ}\right)$ & $\mathrm{I} / \mathrm{I}_{0}$ \\
\hline 0 & 1 & 1 & 8.46927 & $100^{*}$ & 0 & 2 & 1 & 16.41792 & 1.53332 \\
1 & 0 & 0 & 8.82155 & 50.96973 & 1 & 0 & 3 & 16.45854 & 3.72334 \\
0 & 0 & 2 & 8.99789 & 40.19615 & 2 & 1 & -1 & 17.01392 & 7.9014 \\
1 & 1 & 1 & 9.31284 & 40.05874 & 2 & 1 & 2 & 17.4696 & 1.52741 \\
1 & 0 & 1 & 10.06554 & 3.55709 & 0 & 1 & -3 & 17.87741 & 2.06015 \\
0 & 1 & -1 & 10.6696 & 24.81571 & 1 & 1 & -3 & 17.93931 & 2.45911 \\
1 & 1 & -1 & 11.06584 & 20.26129 & 2 & 0 & -1 & 18.08847 & 1.99497 \\
1 & 1 & 2 & 11.39276 & 3.35978 & 2 & 0 & $\mathrm{v} 2$ & 19.55503 & 1.80471 \\
1 & 0 & -2 & 12.3561 & 9.39765 & 2 & 0 & 2 & 20.20981 & 3.97823 \\
1 & 0 & 2 & 12.86607 & 10.83167 & 1 & 0 & 4 & 20.44567 & 1.96777 \\
1 & 2 & 0 & 15.38431 & 1.95101 & 2 & 1 & 4 & 22.8685 & 1.89693 \\
1 & 2 & 2 & 15.49405 & 3.86325 & 2 & 3 & 1 & 23.18129 & 8.72159 \\
1 & -1 & -2 & 15.81212 & 3.41893 & 1 & 3 & -1 & 24.91429 & 5.91526 \\
1 & 0 & -3 & 15.8584 & 5.8791 & & & & & \\
\hline
\end{tabular}

${ }^{\star}$ Only the most significant peaks are considered. 


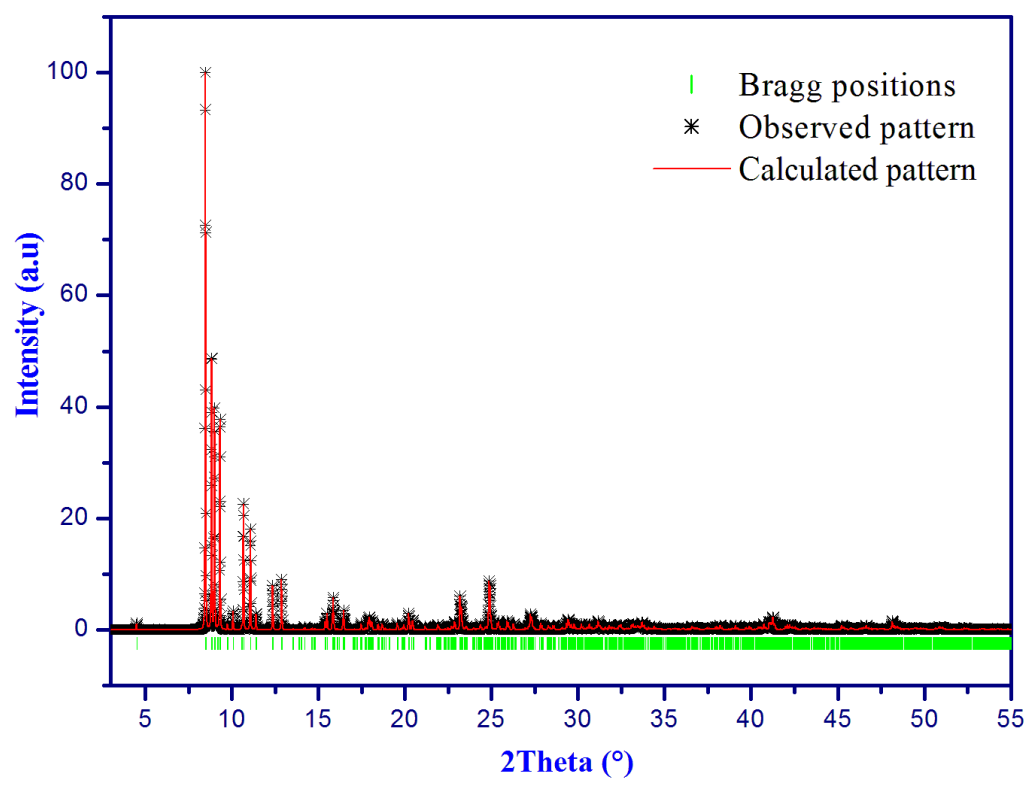

Figure 1. Experimental and calculated diffractogram DRX of compound (1).

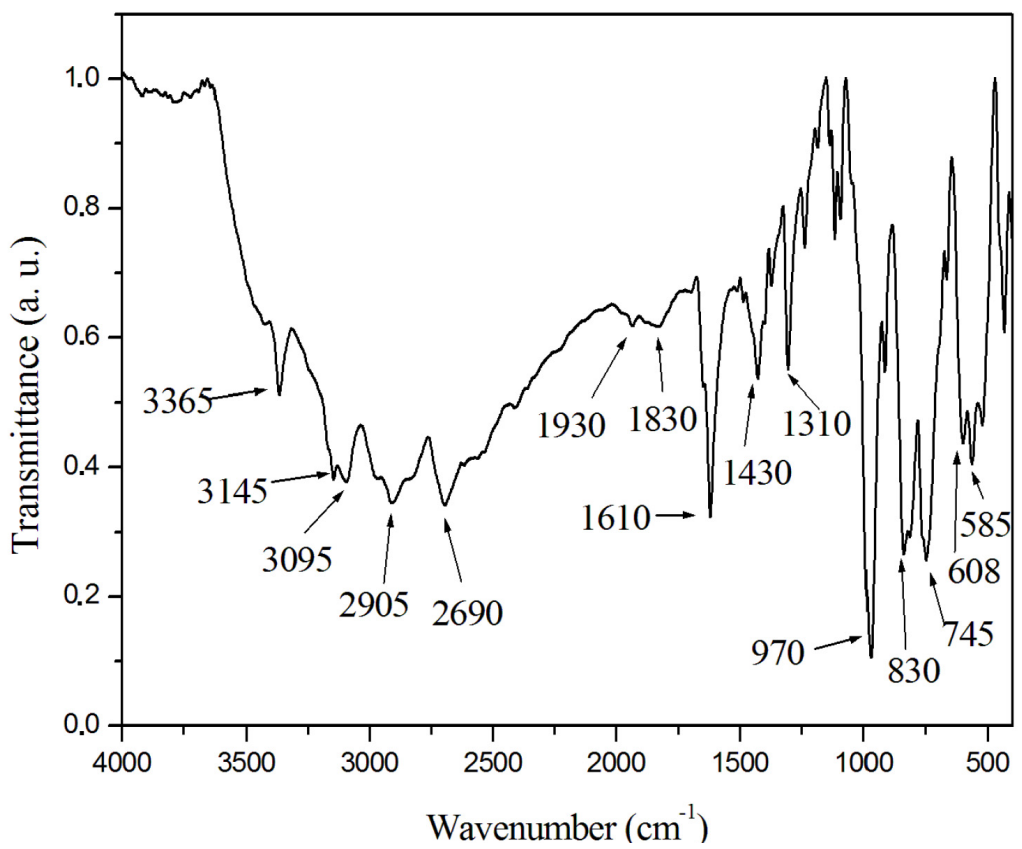

Figure 2. Infrared spectra of compound (1).

$\mathrm{V}-\mathrm{O}_{3 \mathrm{~b}}$ bond distances range from 1.929(4) and 2.059(4) $\AA$. The $\mathrm{V}-\mathrm{O}_{6 \mathrm{~b}}$ bond lengths are within 2.061(4) and 2.374(4) $\AA$. The V-V distances are in the range 3.051(1) to 3.120(1) ^.

The 2-methylimidazolium $\left(\mathrm{C}_{4} \mathrm{~N}_{2} \mathrm{H}_{7}\right)^{+}$and 2-amino-4-picolinium $\left(\mathrm{C}_{6} \mathrm{~N}_{2} \mathrm{H}_{10}\right)^{2+}$ cations forming two different alternating layers. The first layer is composed by 2-amino-4-picolinium $\left(\mathrm{C}_{6} \mathrm{~N}_{2} \mathrm{H}_{10}\right)^{2+}$ and 2-methylimidazolium $\left(\mathrm{C}_{4} \mathrm{~N}_{2} \mathrm{H}_{7}\right)^{+}$cations. The second layer is formed by 2-methylimidazolium $\left(\mathrm{C}_{4} \mathrm{~N}_{2} \mathrm{H}_{7}\right)^{+}$cations (Figure 5). The bond lengths of $\mathrm{C}-\mathrm{C}$ and $\mathrm{C}-\mathrm{N}$ are from 1.353(1) to 1.502(1) $\AA$ and from 


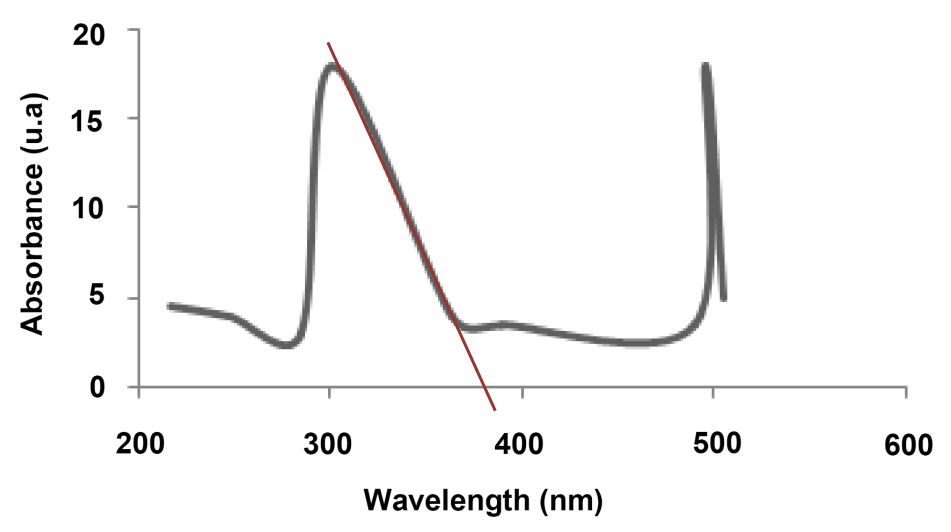

Figure 3. UV-Vis spectra of compound (1).

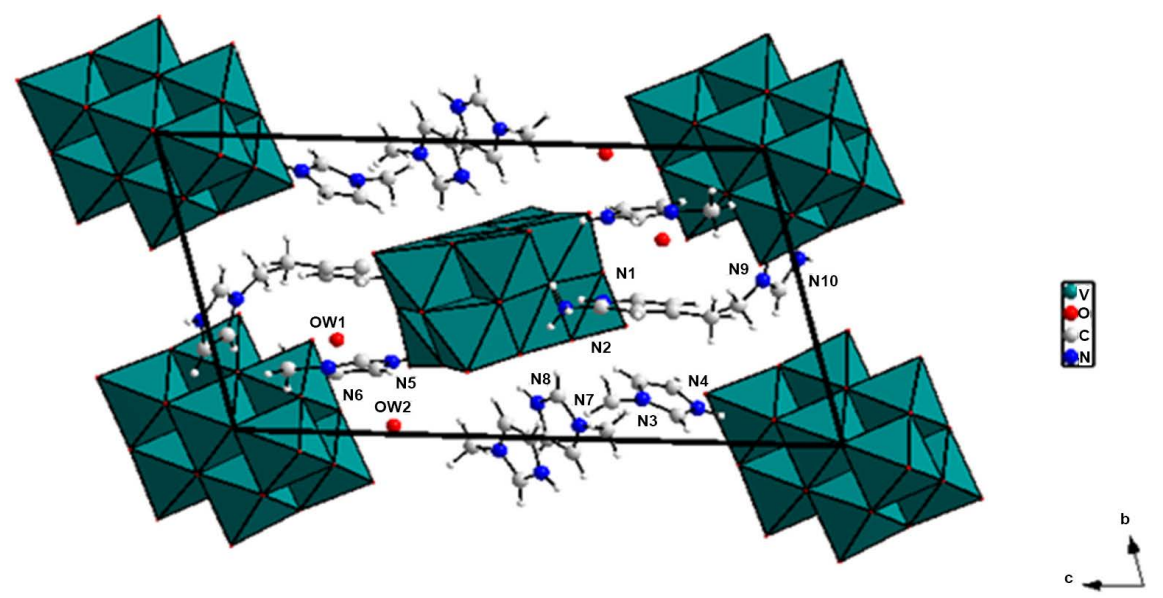

Figure 4. Projection of the $\left(\mathrm{C}_{4} \mathrm{~N}_{2} \mathrm{H}_{7}\right)_{4}\left(\mathrm{C}_{6} \mathrm{~N}_{2} \mathrm{H}_{10}\right) \mathrm{V}_{10} \mathrm{O}_{28} \cdot 2 \mathrm{H}_{2} \mathrm{O}$ compound along the a-axis. Hydrogen atoms are omitted for clarity.

Table 3. Distortion, indexes ID and BVS calculations for $\left(\mathrm{C}_{4} \mathrm{~N}_{2} \mathrm{H}_{7}\right)_{4}\left(\mathrm{C}_{6} \mathrm{~N}_{2} \mathrm{H}_{10}\right) \mathrm{V}_{10} \mathrm{O}_{28} \cdot 2 \mathrm{H}_{2} \mathrm{O}$.

\begin{tabular}{|c|c|c|c|c|c|}
\hline Octahedra & ${\mathrm{V} 1 \mathrm{O}_{6}}$ & $\mathrm{~V}_{2} \mathrm{O}_{6}$ & $\mathrm{~V}_{3} \mathrm{O}_{6}$ & $\mathrm{~V}_{4} \mathrm{O}_{6}$ & $\mathrm{~V} 5 \mathrm{O}_{6}$ \\
\hline BVS & $\Sigma s i=4.95$ & $\Sigma \mathrm{si}=4.95$ & $\Sigma s i=4.99$ & $\Sigma s i=4.94$ & $\Sigma s i=5.00$ \\
\hline ID & $\mathrm{ID}=7.6 \%$ & $\mathrm{ID}=9.2 \%$ & $\mathrm{ID}=9.1 \%$ & $\mathrm{ID}=9.1 \%$ & ID $=9.1 \%$ \\
\hline Octahedra & $\mathrm{V} 6 \mathrm{O}_{6}$ & $\mathrm{~V} \mathrm{O}_{6}$ & ${\mathrm{~V} 8 \mathrm{O}_{6}}$ & $\mathrm{~V} 9 \mathrm{O}_{6}$ & $\mathrm{~V} 10 \mathrm{O}_{6}$ \\
\hline BVS & $\Sigma s i=4.94$ & $\Sigma s i=5.00$ & $\Sigma s i=4.90$ & $\Sigma \mathrm{si}=4.96$ & $\Sigma \mathrm{si}=5.00$ \\
\hline ID & $\mathrm{ID}=7.9 \%$ & $\mathrm{ID}=8.8 \%$ & $\mathrm{ID}=9.9 \%$ & $\mathrm{ID}=8.7 \%$ & $\mathrm{ID}=9.1 \%$ \\
\hline
\end{tabular}

1.292(1) to 1.511(1) $\AA$, respectively. These bond lengths are in agreement with those reported in literature [33] [34].

Decavanadate groups, organic cations and water molecules form infinite zigzag chains viewed along the $\mathrm{c}$ axis as shown in Figure 6. The cohesion of these layers by $\mathrm{N}-\mathrm{H} \ldots \mathrm{O}, \mathrm{O}-\mathrm{H} \ldots \mathrm{O}$ hydrogen bonds and Van der Waals interactions leads to a three-dimensional structure.

The decavanadate groups form hydrogen bonds on the one hand with the water molecules and on the other hand with the organic molecules. Similarly organic cations form hydrogen bonds with oxygen atoms of $\mathrm{V}_{10} \mathrm{O}_{28}^{6-}$ groups and 


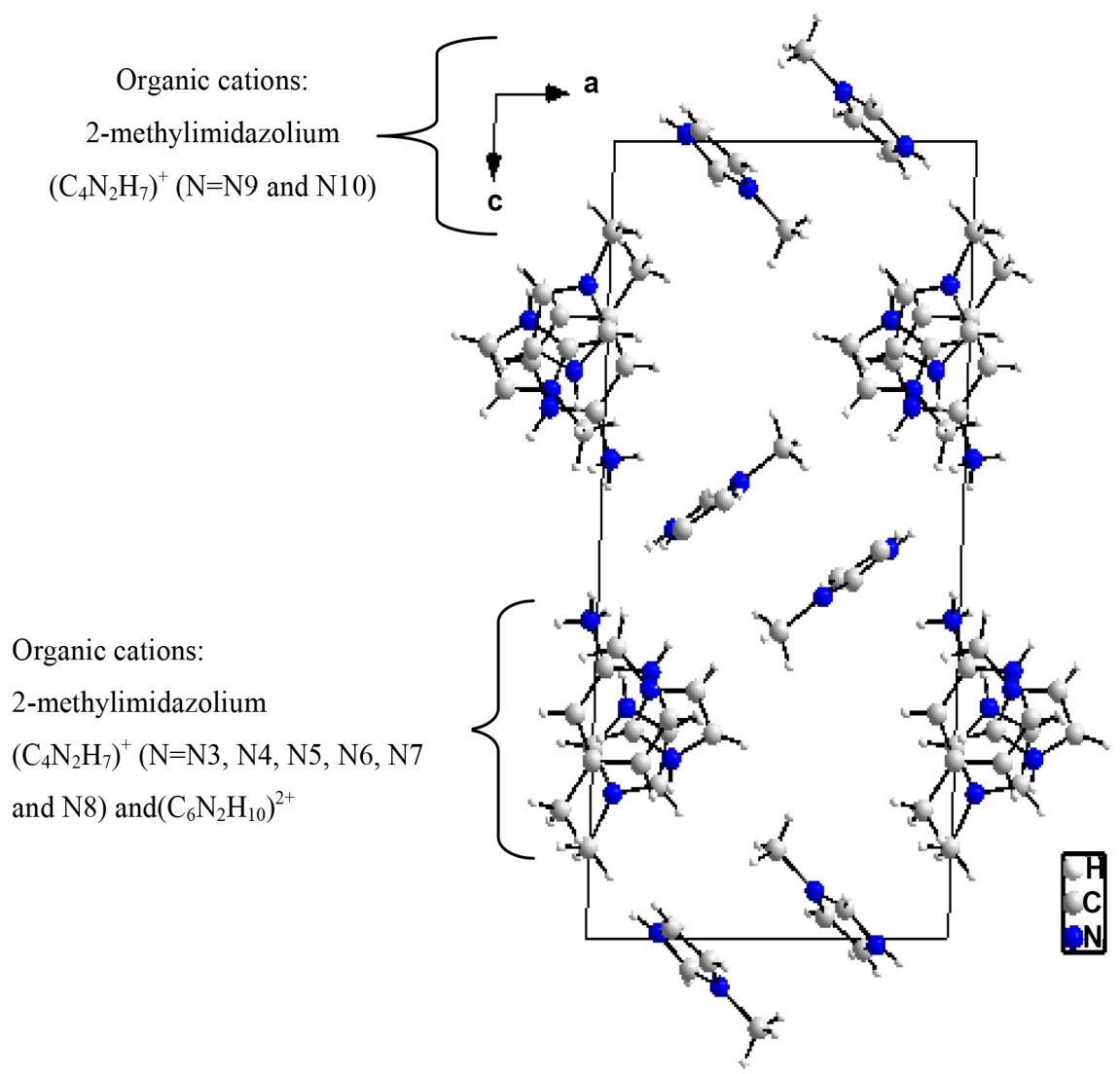

Figure 5. Projection along the b-axis of the organic cations in the $\left(\mathrm{C}_{4} \mathrm{~N}_{2} \mathrm{H}_{7}\right)_{4}\left(\mathrm{C}_{6} \mathrm{~N}_{2} \mathrm{H}_{10}\right) \mathrm{V}_{10} \mathrm{O}_{28} \cdot 2 \mathrm{H}_{2} \mathrm{O}$ compound.

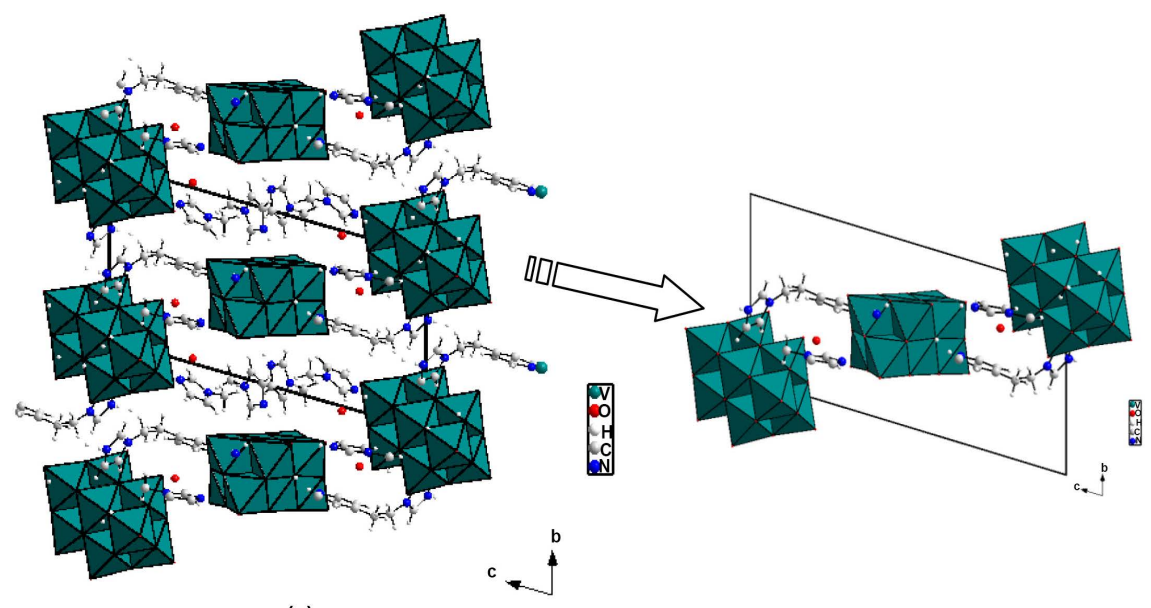

(a)

(b)

Figure 6. (a) Structure view of compound (1) along the a-axis. (b) Disposition of the layers parallel to the plane (011).

water molecules (Figure 7). In this structure, five hydrogen bonds are strong with a range of $\mathrm{D}$--- $\mathrm{A}$ bond lengths from 2.677 to $2.876 \AA$ and the other five are weak with the D---A bond lengths vary from 3.112 to $3.350 \AA$ according to Brown [35] (Table 4). 


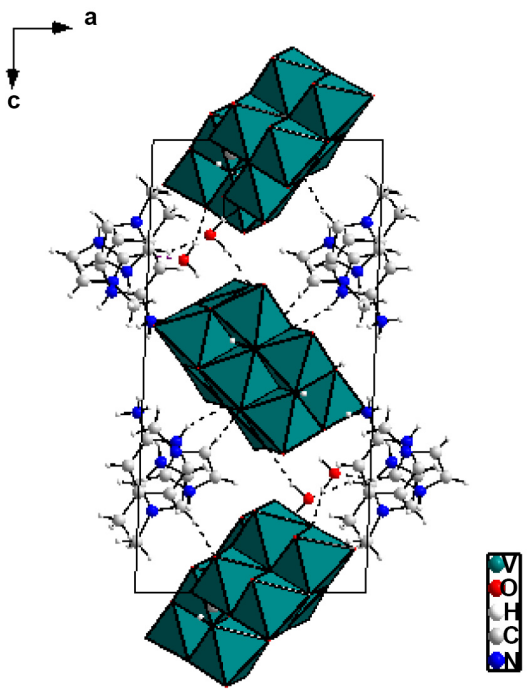

Figure 7. Representation of hydrogen bonds in the $\left(\mathrm{C}_{4} \mathrm{~N}_{2} \mathrm{H}_{7}\right)_{4}\left(\mathrm{C}_{6} \mathrm{~N}_{2} \mathrm{H}_{10}\right) \mathrm{V}_{10} \mathrm{O}_{28} \cdot 2 \mathrm{H}_{2} \mathrm{O}$ compound.

Table 4. Hydrogen bonds in crystal of (1).

\begin{tabular}{|c|c|c|c|c|}
\hline D-H...A & D-H $(\AA)$ & H...A $(\AA)$ & D...A $(\AA)$ & D-H...A $\left({ }^{\circ}\right)$ \\
\hline OW1-H27....O2 & 0.958 & 1.919 & 2.860 & 166.78 \\
\hline OW1-H28....O23 & 0.959 & 2.047 & 2.772 & 131.02 \\
\hline OW1-H28 ....O25 & 0.959 & 2.500 & 3.269 & 137.19 \\
\hline OW2-H30....O15 & 0.930 & 1.984 & 2.854 & 155.13 \\
\hline $\mathrm{N} 1-\mathrm{H} 5 \ldots . . \mathrm{O} 3$ & 0.860 & 1.875 & 2.677 & 154.52 \\
\hline N2-H6A....O $6^{\mathrm{ii}}$ & 0.890 & 2.506 & 3.186 & 133.60 \\
\hline N2-H6A....O10 & 0.890 & 2.506 & 3.186 & 133.60 \\
\hline N2-H6B....O12 & 0.890 & 2.441 & 2.876 & 110.55 \\
\hline $\mathrm{N} 5-\mathrm{H} 16 \ldots . \mathrm{O} 9^{\mathrm{IVi}}$ & 0.860 & 2.384 & 3.112 & 142.69 \\
\hline $\mathrm{N} 8-\mathrm{H} 21 \ldots . . \mathrm{O} 9^{\mathrm{Vi}}$ & 0.860 & 2.428 & 3.230 & 155.52 \\
\hline
\end{tabular}

Symmetry codes: (i) $-\mathrm{x}+1,-\mathrm{y}+1,-\mathrm{z}$; (ii) $-\mathrm{x},-\mathrm{y}+1,-\mathrm{z}+1$; (iii) $\mathrm{x}-1, \mathrm{y}, \mathrm{z}$; (ivi) $-\mathrm{x}+1,-\mathrm{y}+1,-\mathrm{z}+1$; (vi) $\mathrm{x}-1, \mathrm{y}, \mathrm{z}$.

\section{Conclusion and Perspectives}

A novel decavanadate has been synthesized and characterized by single crystal $\mathrm{X}$-ray diffraction, IR and UV-Vis spectroscopies. The decavanadates anions, organic cations and the water molecules are connected through $\mathrm{N}-\mathrm{H} \cdots \mathrm{O}, \mathrm{O}-\mathrm{H} \cdots \mathrm{O}$ hydrogen bonds and Van der Waals interactions to form a three-dimensional structure. In perspective, biological analyzes will be carried out, as part of a project with the Institute of Pasteur of Tunis, to better understand the mode of action of vanadium crystals developed and therefore evaluate their effect on the germination of spores. Germination tests are also very useful for evaluating the mechanism of action of the antifungal compounds. 


\section{Acknowledgements and Funding Information}

Financial support from the Ministry of Higher Education and Scientific Research of Tunisia is gratefully acknowledged.

\section{Conflicts of Interest}

The authors declare no conflicts of interest regarding the publication of this paper.

\section{References}

[1] Bregeault, J.M., Vennat, M., Salles, L., Piquemal, J.Y., Mahha, Y., Briot, E., Bakala, P.C., Atlamsani, A. and Thouvenot, R. (2006) From Polyoxometalates to Polyoxoperoxometalates and Back Again; Potential Applications. Journal of Molecular Catalysis $A$, 250, 177-181. https://doi.org/10.1016/j.molcata.2006.01.027

[2] Coronado, E. and Day, P. (2004) Magnetic Molecular Conductors. Chemical Reviews, 104, 5419-5448. https://doi.org/10.1021/cr030641n

[3] Huang, X., Li, J., Shen, G., Xin, N., Lin, Z., Chi, Y., Dou, J., Li, D. and Hu, C. (2017) Three Pd-Decavanadates with a Controllable Molar Ratio of Pd to Decavanadate and Their Heterogeneous Aerobic Oxidation of Benzylic C-H Bonds. Dalton Transactions, 47, 726-733. https://doi.org/10.1039/C7DT03898D

[4] Wang, C., Chen, Z., Yao, X., Chao, Y., Xun, S., Xiong, J., Fan, L., Zhu, W. and Li, H. (2018) Decavanadates Anchored into Micropores of Graphene-Like Boron Nitride: Efficient Heterogeneous Catalysts for Aerobic Oxidative Desulfurization. Fuel, 230, 104-112. https://doi.org/10.1016/j.fuel.2018.04.153

[5] Aureliano, M. (2014) Decavanadate Contribution to Vanadium Biochemistry: In Vitro and in Vivo Studies. Inorganica Chimica Acta, 420, 4-7.

https://doi.org/10.1016/j.ica.2013.10.010

[6] Aureliano, M. and Ohlin, C.A. (2014) Decavanadate in Vitro and in Vivo Effects: Facts and Opinions. Journal of Inorganic Biochemistry, 137, 123-130.

https://doi.org/10.1016/j.jinorgbio.2014.05.002

[7] Galani, A., Tsitsias, V., Stellas, D., Psycharis, V., Raptopoulou, C.P. and Karaliota, A. (2015) Two Novel Compounds of Vanadium and Molybdenum with Carnitine Exhibiting Potential Pharmacological Use. Journal of Inorganic Biochemistry, 142, 109-117. https://doi.org/10.1016/j.jinorgbio.2014.10.004

[8] Treviño, S., Sánchez-Lara, E., Sarmiento-Ortega, V., Sánchez-Lombardo, I., Flores-Hernández, J., Pérez-Benítez, A., Brambila-Colombres, E. and González-Vergara, E. (2015) Hypoglycemic, Lipid-Lowering and Metabolic Regulation Activities of Metforminium Decavanadate $\left(\mathrm{H}_{2} \mathrm{Metf}\right)_{3}\left[\mathrm{~V}_{10} \mathrm{O}_{28}\right] \cdot 8 \mathrm{H}_{2} \mathrm{O}$ Using Hypercaloric-Induced Carbohydrate and Lipid Deregulation in Wistar Rats as Biological Model. Journal of Inorganic Biochemistry, 147, 85-92. https://doi.org/10.1016/j.jinorgbio.2015.04.002

[9] Choi, H., Chang, Y.Y., Kwon, Y.U. and Han, O.H. (2003) Incorporation of Decavanadate Ions into Silica Gels and Mesostructured Silica Walls. Chemistry of Materials, 15, 3261-3267. https://doi.org/10.1021/cm034061i

[10] Martín-Caballero, J., Wéry, A.S.J., Reinoso, S., Artetxe, B., Felices, L.S., Bakkali, B.E., Trautwein, G., Alcañiz-Monge, J., Vilas, J.L. and Gutiérrez-Zorrilla, J.M. (2016) A Robust Open Framework Formed by Decavanadate Clusters and Copper(II) Complexes of Macrocyclic Polyamines: Permanent Microporosity and Catalytic Oxidation of Cycloalkanes. Inorganic Chemistry, 55, 4970-4979. https://doi.org/10.1021/acs.inorgchem.6b00505 
[11] Baruah, B., Roden, J.M., Sedgwick, M., Correa, N.M., Crans, D.C. and Levinger, N.E. (2006) When Is Water Not Water? Exploring Water Confined in Large Reverse Micelles Using a Highly Charged Inorganic Molecular Probe. Journal of the American Chemical Society, 128, 12758-12765. https://doi.org/10.1021/ja0624319

[12] Nomiya, K., Torii, H., Hasegawa, T., Nemoto, Y., Nomura, K., Hashino, K., Uchida, M., Kato, Y., Shimizu, K. and Oda, M. (2001) Insulin Mimetic Effect of a Tungstate Cluster. Effect of Oral Administration of Homo-Polyoxotungstates and Vanadium-Substituted Polyoxotungstates on Blood Glucose Level of STZ Mice. Journal of Inorganic Biochemistry, 86, 657-667. https://doi.org/10.1016/S0162-0134(01)00233-1

[13] Wang, M., Sun, W., Pang, H., Ma, H., Yu, J., Zhang, Z., Niu, Y. and Yin, M. (2016) Tuning the Microstructures of Decavanadate-Based Supramolecular Hybrids via Regularly Changing the Spacers of Bis(triazole) Ligands. Journal of Solid State Chemistry, 235, 175-182. https://doi.org/10.1016/j.jssc.2015.12.033

[14] Ma, H., Meng, X., Sha, J., Pang, H. and Wu, L. (2011) Synthesis, Crystal Structure and Properties of a New Bi-Dentate Decavanadate $\left[\mathrm{Cu}(\mathrm{en})_{2} \mathrm{H}_{2} \mathrm{O}\right] 2\left[\mathrm{H}_{2} \mathrm{~V}_{10} \mathrm{O}_{28}\right] \cdot 12 \mathrm{H}_{2} \mathrm{O}$. Solid State Sciences, 13, 850-854. https://doi.org/10.1016/j.solidstatesciences.2011.03.007

[15] Li, S., Sun, W., Wang, K., Ma, H., Pang, H., Liu, H. and Zhang, J. (2014) Turn Helical Motifs from Pair to Single Entangled Double Helixes in a Cobalt-Vanadate System via Introduction of a V-Shaped Ligand. Inorganic Chemistry, 53, 4541-4547. https://doi.org/10.1021/ic500224m

[16] Klištincová, L., Rakovský, E. and Schwendt, P. (2008) Decavanadate Ion as Bridging Ligand. Synthesis and Crystal Structure of $\left(\mathrm{NH}_{4}\right)_{2}\left[\mathrm{Cu}_{2}\left(\mathrm{NH}_{3} \mathrm{CH}_{2} \mathrm{CH}_{2} \mathrm{COO}\right)_{4^{-}}\right.$ $\left.\left(\mathrm{V}_{10} \mathrm{O}_{28}\right)\right] \cdot 10 \mathrm{H}_{2} \mathrm{O}$. Inorganic Chemistry Communications, 11, 1140-1142.

[17] Putrevu, N.R., Doedens, R.J. and Khan, M.I. (2013) Decavanadate with a Novel Coordination Complex: Synthesis and Characterization of $\left(\mathrm{NH}_{4}\right)_{2}\left[\mathrm{Ni}\left(\mathrm{H}_{2} \mathrm{O}\right)_{5}\left(\mathrm{NH}_{3}\right)\right]_{2}$ $\left(\mathrm{V}_{10} \mathrm{O}_{28}\right) \cdot 4 \mathrm{H}_{2} \mathrm{O}$. Inorganic Chemistry Communications, 38, 5-7.

[18] Chatkon, A., Barres, A., Samart, N., Boyle, S.E., Haller, K.J. and Crans, D.C. (2014) Guanylurea Metformium Double Salt of Decavanadate, $\left(\mathrm{HGU}^{+}\right)_{4}\left(\mathrm{HMet}^{+}\right)_{2}\left(\mathrm{~V}_{10} \mathrm{O}_{28}{ }^{6-}\right) \cdot 2 \mathrm{H}_{2} \mathrm{O}$. Inorganica Chimica Acta, 420, 85-95. https://doi.org/10.1016/j.ica.2013.12.031

[19] Truflandier, L.A., Boucher, F., Payen, C., Hajjar, R., Millot, Y., Bonhomme, C. and Steunon, N. (2010) DFT-NMR Investigation and 51V 3QMAS Experiments for Probing Surface $\mathrm{OH}$ Ligands and the Hydrogen-Bond Network in a Polyoxovanadate Cluster: The Case of $\mathrm{Cs}_{4}\left[\mathrm{H}_{2} \mathrm{~V}_{10} \mathrm{O}_{28}\right] \cdot 4 \mathrm{H}_{2} \mathrm{O}$. Journal of the American Chemical Society, 132, 4653-4668. https://doi.org/10.1021/ja908973y

[20] Kodama, S., Taya, N. and Ishii, Y. (2014) A Novel Octanuclear Vanadium(V) Oxide Cluster Complex Having an Unprecedented Neutral $\mathrm{V}_{8} \mathrm{O}_{20}$ Core Functionalized with 4,4'-Di-tert-butyl-2,2'-bipyridine. Inorganic Chemistry, 53, 2754-2756. https://doi.org/10.1021/ic4031393

[21] Graia, M., Ksiksi, R. and Driss, A. (2009) Nonapiperidinium Monohydrogen Deca-Vanadate Tetra-Nitrate. Acta Crystallographica E, 65, m953-m954. https://doi.org/10.1107/S1600536809026555

[22] Rakovsky, E. and Krivosudsky, L. (2014) Tetrakis(2,6-di-methyl-pyridinium) DiHydrogen Deca-Vanadate Dehydrate. Acta Crystallographica E, 70, m225-m226. https://doi.org/10.1107/S1600536814011118

[23] Fernadez de Luis, R., Urtiaga, M.K., Mesa, J.L. and Arriortua, M.I. (2010) Tris[4,4' (ethene-1,2-di-yl)dipyridinium] Deca-Vanadate Dehydrate. Acta Crystallographica E, 66, m323-m324. https://doi.org/10.1107/S1600536810006215 
[24] Omri, I., Mhiri, T. and Graia, M. (2016) A New Monohydrogendecavanadate (V)-Dihydrogendecavanadate (V) with Dibutylammonium Cations $\left[\mathrm{C}_{8} \mathrm{NH}_{20}\right]_{9}$ $\left[\mathrm{H}_{2} \mathrm{~V}_{10} \mathrm{O}_{28}\right]\left[\mathrm{HV}_{10} \mathrm{O}_{28}\right] .2 .13 \mathrm{H}_{2} \mathrm{O}$ : Synthesis, Crystal Structure, Vibrational and Optical Properties. Journal of Molecular Structure, 1108, 334-340.

[25] Sheldrick, G.M. (2008) A Short History of SHELX. Acta Crystallographica A, 64, 112-122. https://doi.org/10.1107/S0108767307043930

[26] Sheldrick, G.M. (2015) Crystal Structure Refinement with SHELXL. Acta Crystallographica C, 71, 3-8. https://doi.org/10.1107/S2053229614024218

[27] Brandenburg, K. (2001) DIAMOND Version 2.1e Crystal Impact GbR Bonn Germany.

[28] Microcal Origin Version 8.0 (1991-2009). Microcal Software Inc. One, Northampton.

[29] Momma, K. and Izumi, F. (2011) VESTA 3 for Three-Dimensional Visualization of Crystal, Volumetric and Morphology Data. Journal of Applied Crystallography, 44, 1272-1276. https://doi.org/10.1107/S0021889811038970

[30] Baur, W.H. (1974) The Geometry of Polyhedral Distortions. Predictive Relationships for the Phosphate Group. Acta Crystallographica B, 30, 1195-1215. https://doi.org/10.1107/S0567740874004560

[31] Brown, I.D. (1992) Chemical and Steric Constraints in Inorganic Solids. Acta Crystallographica B, 48, 553-572. https://doi.org/10.1107/S0108768192002453

[32] Bresse, N.E. and O'Keeffe, M. (1991) Bond-Valence Parameters for Solids. Acta Crystallographica B, 47, 192-197. https://doi.org/10.1107/S0108768190011041

[33] Siddiqi, Z.A., Sharma, P.K., Shahid, M., Kalid, M., Siddique, A. and Kumar, S. (2012) Novel Decavanadate Cluster Complexes $\left[\mathrm{H}_{2} \mathrm{~V}_{10} \mathrm{O}_{28}\right][\mathrm{LH}]_{4} \cdot \mathrm{nH}_{2} \mathrm{O}(\mathrm{L}=$ Imidazole, $\mathrm{n}=2$ or 2-Methylimidazole, $\mathrm{n}=0$ ): Preparation, Characterization and Genotoxic Studies. Journal of Molecular Structure, 1029, 86-91. https://doi.org/10.1016/j.molstruc.2012.06.035

[34] Yan, J., Zhao, H., Li, Z., Xing, Y., Zeng, X., Ge, M. and Niu, S. (2009) A Self-Assembled 3D Hydrogen Bonded Network Constructed from Polyoxovanadate and Protonated Organic Substrate with a Solvent Hydrolysis Reaction. Journal of Cluster Science, 20, 717-724. https://doi.org/10.1007/s10876-009-0274-1

[35] Brown, I.D. (1976) On the Geometry of O-H...O Hydrogen Bonds. Acta Crystallographica A, 32, 24-31. https://doi.org/10.1107/S0567739476000041 